\title{
Discovery of a small-molecule inhibitor for kidney ADP-ribosyl cyclase: Implication for intracellular calcium signal mediated by cyclic ADP-ribose
}

\author{
Tae-Sik Nam ${ }^{1 *}$ Sung Hoon $\mathrm{Choi}^{3 *}$, \\ So-Young Rah ${ }^{1}$, Seon-Young Kim ${ }^{1}$, \\ Won Jang ${ }^{1}$, Mie-Jae Im $^{1}$, \\ Ho Jeong Kwon ${ }^{3,4}$ and Uh-Hyun Kim ${ }^{1,2,4}$ \\ ${ }^{1}$ Department of Biochemistry \\ ${ }^{2}$ The Institute of Cardiovascular Research \\ Chonbuk National University Medical School \\ Jeonju 561-182, Korea \\ ${ }^{3}$ Chemical Genomics Laboratory \\ Department of Biotechnology \\ College of Engineering, Yonsei University \\ Seoul 120-749, Korea \\ ${ }^{4}$ Corresponding authors: Tel, 82-63-270-3083 (UHK); \\ 82-2-2123-5883 (HJK); \\ Fax, 82-63-274-9833 (UHK); 82-2-362-7265 (HJK); \\ E-mail, uhkim@chonbuk.ac.kr (UHK); kwonhj@yonsei.ac.kr (HJK) \\ *These authors contributed equally to this work.
}

Accepted 20 November 2006

Abbreviations: ADPR-cyclase, ADP-ribosyl cyclase; $\left[\mathrm{Ca}^{2+}\right]$, intracellular $\mathrm{Ca}^{2+}$ concentration; $\left[\mathrm{Ca}^{2+}\right]_{0}$, extracellular calcium ion; CADPR, cyclic ADP-ribose; CaSR, extracellular calcium-sensing receptor; $\mathrm{DHAB}, 4,4$ '-dihydroxy-azobenzene; MMC, mouse kidney mesangial cells; $\mathrm{NGD}^{+}$, nicotinamide guanine dinucleotide

\begin{abstract}
ADP-ribosyl cyclase (ADPR-cyclase) produces a $\mathrm{Ca}^{2+}$-mobilizing second messenger, cyclic ADPribose (CADPR), from $\beta-N A D^{+}$. A prototype of mam malian ADPR-cyclases is a lymphocyte antigen CD38. Accumulating evidence indicates that ADPR-cyclases other than CD38 are expressed in various cells and organs. In this study, we discovered a small molecule inhibitor of kidney ADPR-cyclase. This compound inhibited kidney ADPR-cyclase activity but not CD38, spleen, heart or brain ADPR-cyclase activity in vitro. Characterization of the compound in a cell-based system revealed that an extracellular calcium-sensing receptor (CaSR)mediated CADPR production and a later long-lasting increase in intracellular $\mathrm{Ca}^{2+}$ concentration $\left(\left[\mathrm{Ca}^{2+}\right]_{i}\right)$ in mouse mesangial cells were inhibited by the pre-treatment with this compound. In contrast, the compound did not block CD3/TCR-induced CADPR production and the increase of $\left[\mathrm{Ca}^{2+}\right]_{i}$ in Jurkat $\mathrm{T}$ cells,
\end{abstract}

which express CD38 exclusively. The long-lasting $\mathrm{Ca}^{2+}$ signal generated by both receptors was in hibited by pre-treatment with an antagonistic CADPR derivative, 8-Br-CADPR, indicating that the $\mathrm{Ca}^{2+}$ signal is mediated by the ADPR-cyclse metabolite, CADPR. Moreover, among structurally similar com pounds tested, the compound inhibited most potently the cADPR production and $\mathrm{Ca}^{2+}$ signal induced by CaSR. These findings provide evidence for existence of a distinct ADPR-cyclase in the kidney and basis for the development of tissue specific inhibitors.

Keywords: ADP-ribosyl cyclase; antagonists and inhibitors; antigens, CD38; calcium signaling; kidney; mesangial cells

\section{Introduction}

ADP-ribosyl cyclase (ADPR-cyclase) is widely distributed and plays a critical role in regulation of intracellular $\mathrm{Ca}^{2+}$ concentration $\left(\left[\mathrm{Ca}^{2+}\right]_{i}\right)$ via cyclic ADP-ribose (cADPR) production (Guse et al., 1999; Galione et al., 2000; Lee, 2001). The metabolite cADPR is known to increase $\left[\mathrm{Ca}^{2+}\right]_{i}$ by releasing from intracellular $\mathrm{Ca}^{2+}$ stores or by $\mathrm{Ca}^{2+}$ influx through plasma membrane $\mathrm{Ca}^{2+}$ channels in a variety of cells (Guse et al., 1999; Galione et al., 2000; Lee, 2001; Partida-Sanchez et al., 2001). Studies have indicated that a $\mathrm{Zn}^{2+}$-sensitive and reducing agent-insensitive ADPR-cyclase(s), which differs from CD38 or Aplysia californica ADPRcyclase, is present in brain, heart, kidney, arterial smooth muscle cells, and bone marrow cells (Hirata et al., 1994; de Toledo et al., 2000; Ceni et al., 2003; Zielinska et al., 2004; Xie et al., 2005). A study with mice disrupted CD38 gene has demonstrated that formation of CADPR is not reduced greatly in mouse kidney, brain, and heart (PartidaSanchez et al., 2001), suggesting that ADPRcyclases other than CD38 exist. However, the ADPR-cyclase(s) present in these tissues has not been cloned, and the CADPR antagonistic derivatives such as $8-\mathrm{Br}$-CADPR and $8-\mathrm{NH}_{2}$-CADPR do not distinguish the $\mathrm{Ca}^{2+}$ signals induced by the unidentified ADPR-cyclase or CD38 (Walseth and Lee, 1993). Moreover, specific inhibitors of ADPR- 
cyclases have neither been found nor synthesized.

As bioactive small-molecules capable of inducing a specific phenotype serve as tools to probe the functions of protein and signaling pathways (Schreiber, 1998; Kwon, 2003), we expect that specific ADPR-cyclase inhibitors would be useful for demonstrating the existence of kidney ADPR-cyclase, for providing specific tools to distinguish the ADPRcyclase from other ones originated from different tissues, and as potential lead molecules targeting the ADPR-cyclase for therapeutic benefit. To this end, we partially purified ADPR-cyclase from rat kidney, characterized, and screened a chemical library. Here, we report the discovery of a bioactive smallmolecule inhibitor of the kidney ADPR-cyclase.

\section{Materials and Methods}

\section{Materials}

Anti-human CD3 monoclonal antibody (clone OKT3) was obtained from eBioscience (San Diego, CA). Nicotinamide $1, \mathrm{~N}^{6}$-ethenoadenine dinucleotide $\left(\varepsilon^{-}\right.$ $\mathrm{NAD}^{+}$), nicotinamide guanine dinucleotide $\left(\mathrm{NGD}^{+}\right)$, protease inhibitors, heparin-agarose and other chemicals were from Sigma-Aldrich (St. Louis, Mo). Q-Sepharose, Chelating-Sepharose, and CM-Sepharose were purchased from Amersham Biosciences (Piscataway, NJ). 4,4'-Dihydroxyazobenzene (DHAB) and chemical library were purchased from ComGenex (Budapest, Hungary) and Chembridge (San Diego, CA).

\section{Partial purification of ADPR-cyclase from rat kidney}

Kidneys from Sprague-Dawley rats weighing 250$300 \mathrm{~g}$ were washed with ice-cold PBS, minced in a lysis buffer (50 mM HEPES buffer, pH 7.2, $150 \mathrm{mM}$ $\mathrm{NaCl}, 10 \%$ Glycerol, and $1 \mathrm{mM}$ PMSF) and homogenized with a Teflon glass homogenizer in an ice bath. After centrifugation at $500 \times g$ for $10 \mathrm{~min}$, the supernatant was centrifuged at $100,000 \times g$ for $1 \mathrm{~h}$. Pellets obtained were solubilized with $1 \%$ Triton $\mathrm{X}-100$ in the lysis buffer for $1 \mathrm{~h}$. After centrifugation at $100,000 \times g$ for $1 \mathrm{~h}$, the extract was used to purify ADPR-cyclase. We found that ADPR-cyclase did not bind to CM-Sepharose and heparin-agarose and therefore, they were used for the negative purification. The flow-through fractions from these columns were loaded onto $\mathrm{Cu}^{2+}$-chelating Sepharose, washed with five column volume of the lysis buffer containing $0.1 \%$ Triton X-100, and eluted with 200 $\mathrm{mM}$ imidazole in the same buffer. Overall yield was approximately $15 \%$ with 64 -fold purification.

\section{Assays for ADPR-cyclase and cADPR-hydrolase assays}

Specific ADPR-cyclase activity was determined by measuring cyclic GDP-ribose (cGDPR) or ethenoADP-ribose ( $\varepsilon$-ADPR) fluorometrically using $\mathrm{NGD}^{+}$ or $\varepsilon-\mathrm{NAD}^{+}$as a substrate (Greaff et al., 1994). Samples were incubated in the presence of $200 \mu \mathrm{M}$ $\mathrm{NGD}^{+}$or $\varepsilon-\mathrm{NAD}^{+}$with and without an appropriate agent in an assay buffer (25 mM HEPES, $\mathrm{pH} 7.4$, $100 \mathrm{mM} \mathrm{NaCl}$, and $0.1 \%$ Triton $\mathrm{X}-100$ ) in a 50 $\mu \mathrm{l}$-final volume. The reaction mixture was incubated at $37^{\circ} \mathrm{C}$ for $10 \mathrm{~min}$. The reaction was stopped by adding $50 \mu$ trichloroacetic acid $(10 \%)$. The samples were centrifuged at $21,000 \times g$ for $10 \mathrm{~min}$ and the supernatant $(80 \mu \mathrm{l})$ was diluted with $920 \mu \mathrm{l}$ of 100 $\mathrm{mM}$ sodium phosphate buffer $(\mathrm{pH} 7.2)$. Fluorescence of cGDPR or $\varepsilon$-ADPR in the solution was determined at excitation/emission wavelengths of 297/410 nm (HITACHI F-2000 fluorescence spectrophotometer). cADPR-hydrolase activity was determined by incubating CADPR with ADPR-cyclase or CD38 at $37^{\circ} \mathrm{C}$ for $20 \mathrm{~min}$. Hydrolysis of cADPR was analyzed by high performance liquid chromatography as described (White et al., 2000).

\section{Chemical library screening}

Using a chemical library of approximately 10,000 compounds, the screening of ADPR-cyclase inhibitor was conducted in the reaction mixture with partially purified rat kidney ADPR-cyclase, chemical compound, and $200 \mu \mathrm{M} \varepsilon-\mathrm{NAD}^{+}$in the assay buffer in a $50 \mu$-final volume. Formation of CADPR was determined as described above after incubation of the reaction mixtures at room temperature for 60 min. Concentration of compounds used in all enzyme inhibitory assays was $200 \mu \mathrm{M}$ unless otherwise indicated.

\section{Cell culture}

Mouse kidney mesangial cells (MMC) were kindly provided by S. H. Cha (Kwak et al., 2005) and cultured in DMEM supplemented $5 \%$ heat inactivated FBS, $0.25 \mu \mathrm{g} / \mathrm{ml}$ amphotericin $\mathrm{B}$, penicillin $(100 \mathrm{U} / \mathrm{ml})$, and streptomycin $(100 \mathrm{U} / \mathrm{ml})$. Jurkat $\mathrm{T}$ cells were obtained from American Tissue Culture Collection (ATCC, Manassas, VA) and maintained in RPMI 1640 supplemented with 10\% FBS and antibiotics described above. The cells were maintained in a humidified incubator at $37^{\circ} \mathrm{C}$ in the presence of $5 \% \mathrm{CO}_{2}$ and $95 \%$ air.

\section{Measurement of intracellular cADPR concentration [CADPR $]_{\mathrm{i}}$}

[CADPR] $]_{i}$ was measured using a cyclic enzymatic 
A

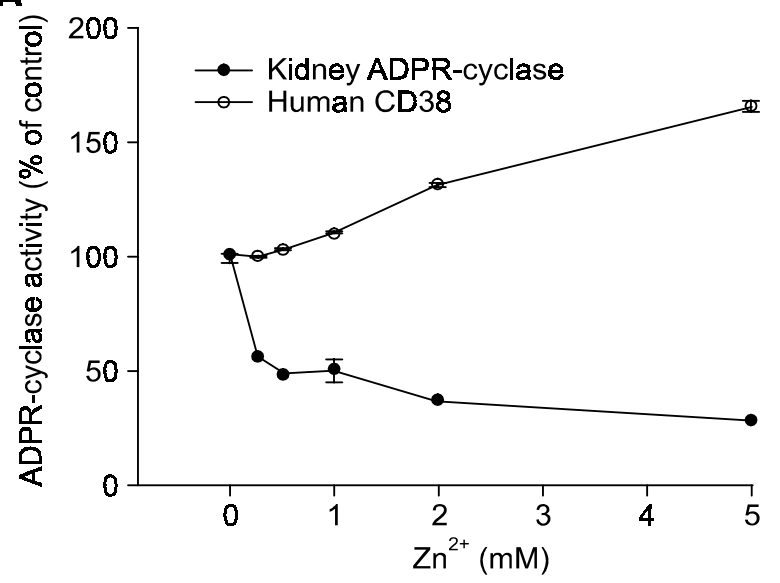

B

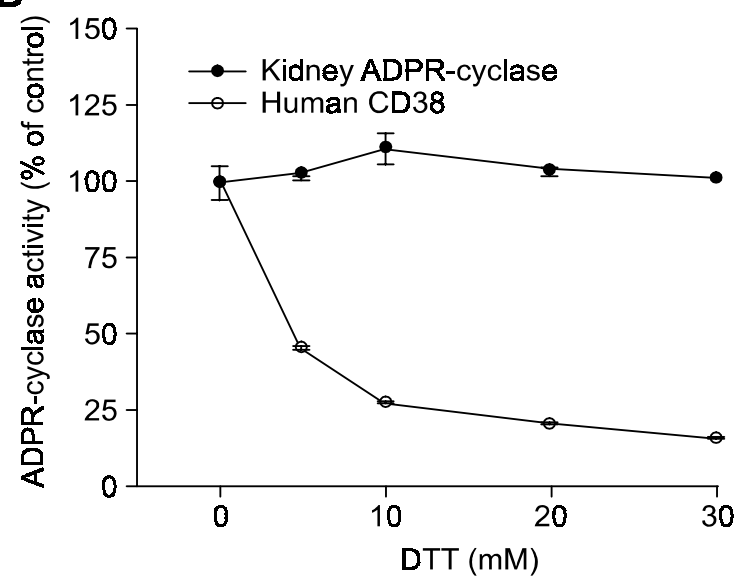

Figure 1. Effects of $\mathrm{Zn}^{2+}$ and DTT on the activity of rat kidney ADPR-cyclase and CD38. Partially purified rat kidney ADPR-cyclase (10 $\mu$ g/assay) or recombinant human $\mathrm{CD} 38$ (10 $\mu \mathrm{g} /$ assay) was incubated with various concentrations of $\mathrm{ZnCl}_{2}(\mathrm{~A})$, and $\mathrm{DTT}(\mathrm{B})$ at $37^{\circ} \mathrm{C}$ for 10 min and the $\mathrm{ADPR}$-cyclase activity was measured by using $\mathrm{NGD}^{+}$as the substrate.

assay as described previously (Graeff and Lee, 2002). Aplysia californica ADPR-cyclase was purified from sea urchin egg according to the method described (Lee and Aarhus, 1991).

\section{Measurement of $\left[\mathrm{Ca}^{2+}\right]_{\mathrm{i}}$}

Changes in $\left[\mathrm{Ca}^{2+}\right]_{i}$ in MMC and Jurkat $\mathrm{T}$ cells were determined as described previously (Kim et al., 2006). Briefly, MMC cultured on confocal dishes for $48 \mathrm{~h}$ or Jurkat $\mathrm{T}$ cells seeded on $100 \mu \mathrm{g} / \mathrm{ml}$ poly L-lysine-coated confocal dishes at a concentration of $10^{4}$ cells/dish were washed with Hank's balanced salt solution (HBSS) $(2 \mathrm{mM} \mathrm{CaCl}, 145 \mathrm{mM} \mathrm{NaCl}, 5$ $\mathrm{mM} \mathrm{KCl}, 1 \mathrm{mM} \mathrm{MgCl} 2,5 \mathrm{mM}$ D-glucose, and $20 \mathrm{mM}$ HEPES, $\mathrm{pH}$ 7.3) and then loaded with $5 \mu \mathrm{M}$ Fluo3 AM (Molecular Probe, Eugene, OR). Changes in $\mathrm{Ca}^{2+}$ fluorescence were determined at $488 \mathrm{~nm} / 530$ $\mathrm{nm}$ (excitation/emission) by air-cooled argon laser system. $\left[\mathrm{Ca}^{2+}\right]_{i}$ was calculated using a $\mathrm{K}_{\mathrm{d}}$ of $325 \mathrm{nM}$ for Fluo3 AM by the method of Tsien et al. (1982).

\section{Cell proliferation assay}

MMC was seeded at a concentration of $5 \times 10^{3}$ cells/well on a 12-well plate. After incubating for 1 day, $10 \mathrm{mM}\left[\mathrm{Ca}^{2+}\right]_{0}$ was treated for 2 days (Kwak et al., 2005). The cells were then detached using $0.25 \%$ trypsin-EDTA, and the number of cells was counted after trypan blue staining to exclude dead cells.

\section{Statistical analysis}

Data represent means \pm standard error of the mean (SEM) of at least three separate experiments.
Statistical analysis was performed using Student's $t$-test. A value of $P<0.05$ was considered significant.

\section{Results and Discussion}

\section{Characterization of ADPR-cyclase from rat kidney}

As a confirmation for the study, we firstly examined whether kidney ADPR-cyclase exhibits different biochemical properties from those of CD38. Zinc ion is known to stimulate the CADPR forming cyclase activity of CD38 but inhibits its cADPR-hydrolase activity and a reducing agent, 1,4-dithiothreitol (DTT) has been shown to inhibit both ADPR-cyclase and cADPR-hydrolase activities (Kukimoto et al., 1996). The effects of these molecules on the kidney ADPR-cyclase and CD38 were evaluated. Zinc stimulated the cyclase activity of CD38 but inhibited kidney ADPR-cyclase activity (Figure 1A). On the other hand, DTT inhibited the cyclase activity of CD38 but exhibited no effect on the kidney ADPRcyclase (Figure 1B). When cADPR-hydrolase activity of the kidney ADPR-cyclase was determined, we found that CADPR-hydrolase activity of the kidney enzyme was not detected whereas CD38 exhibited cADPR-hydrolase activity that was inhibited by $\mathrm{Zn}^{2+}$ (data not shown). These results demonstrate that the kidney ADPR-cyclase is distinct from CD38 in biochemical properties.

\section{Identification of 4,4'-dihydroxy azobenzene (DHAB) as a kidney ADPR-cyclase inhibitor}

Having known that kidney ADPR-cyclase differs 
from CD38, we screened a chemical library of approximately 10,000 compounds for small-molecule inhibitors of the kidney ADPR-cyclase. This screen resulted in the selection of DHAB as a smallmolecule inhibitor (Figure 2A). The compound was able to inhibit generation of CGDPR and $\varepsilon$-ADPR from $\mathrm{NGD}^{+}$and $\varepsilon-\mathrm{NAD}^{+}$, respectively, by the kidney

$\mathbf{A}$

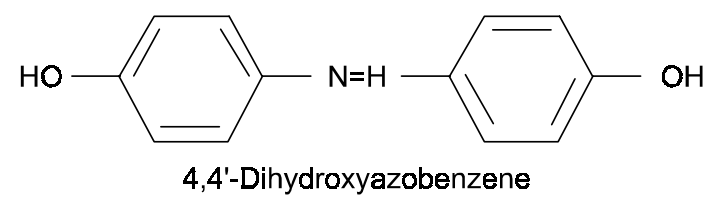

B

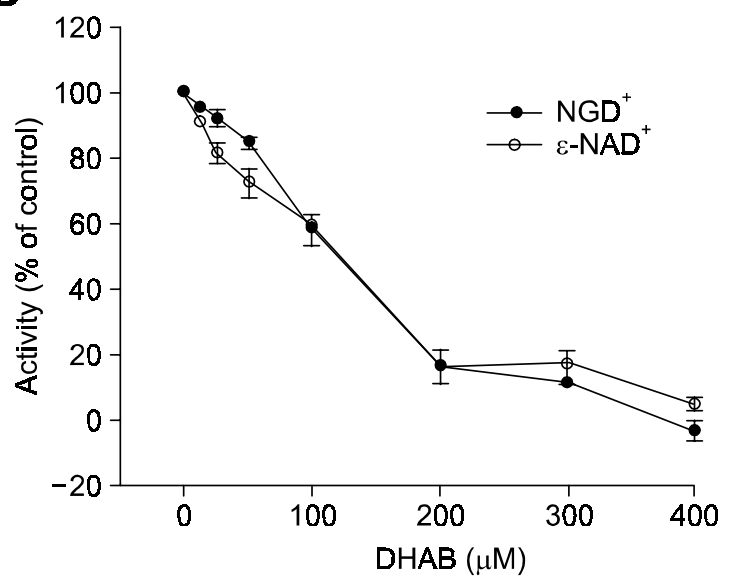

C

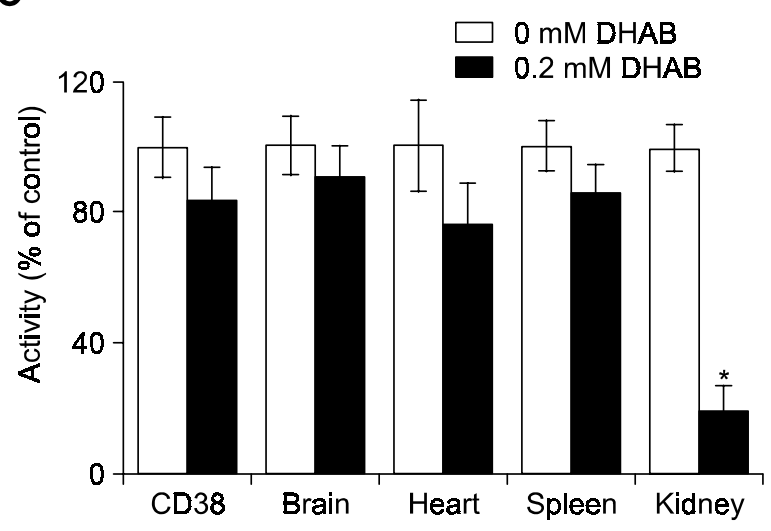

Figure 2. DHAB competes with the substrate of ADPR-cyclase. (A) Structure of DHAB. (B) Inhibition of rat kidney ADPR-cyclase by DHAB. The enzyme $(10 \mu \mathrm{g} / \mathrm{tube})$ was incubated with $200 \mu \mathrm{M} \mathrm{NGD}^{+}$or $\varepsilon-N A D^{+}$in the presence of various concentrations of DHAB at $37^{\circ} \mathrm{C}$ for $10 \mathrm{~min}$. DAHB was preincubated with the enzyme at $4^{\circ} \mathrm{C}$ for $1 \mathrm{~h}$. (C) Effects of DHAB on human CD38, rat brain, heart, spleen, and kidney ADPR-cyclase. The mean \pm SEM of three independent experiments is shown. ${ }^{*}$ Control versus DHAB, $P<0.001$.
ADPR-cyclase in a concentration-dependent manner. These data suggest that the compound may bind to the active site of the enzyme. Half maximal inhibition $\left(\mathrm{IC}_{50}\right)$ of the enzyme activity was approximately $100 \mu \mathrm{M}$ (Figure 2B). CD38 and ADPRcyclases purified partially from rat brain, heart, and spleen tissues were insensitive to DHAB at $200 \mu \mathrm{M}$ (Figure 2C).

\section{Stimulation of extracellular calcium ion} $\left(\left[\mathrm{Ca}^{2+}\right]_{0}\right)$-sensing receptor (CaSR) in mouse mesangial cells (MMC) produces CADPR and a long-lasting $\mathrm{Ca}^{2+}$ signal

Inhibitory potency of DHAB on the ADPR-cyclase activity is critical for studying the signaling or inducing phenotype in a cell-based system. In MMC, an ADPR-cyclase activating receptor has not been identified. However, a number of $G$ protein-coupled receptors (GPCRs) have been shown to utilize ADPR-cyclase in regulation of $\left[\mathrm{Ca}^{2+}\right]_{i}$ (Higashida et al., 1999; 2000; Boittin et al., 2003; Ge et al., 2003; Sternfeld et al., 2003; Fellner and Arendshorst, 2005). We examined several ligands of GPCRs, which are known to stimulate cADPR production in various cells upon binding to the cognate receptor. Among them, stimulation of CaSR with $\left[\mathrm{Ca}^{2+}\right]_{0}$ resulted in a significant increase of [CADPR], (Figure $3 \mathrm{~A})$ and a generation of long-lasting increase of $\left[\mathrm{Ca}^{2+}\right]_{i}$, a burst $\mathrm{Ca}^{2+}$ rise followed by a sustained $\mathrm{Ca}^{2+}$ rise that was gradually decreased (Figure 3B). The sustained $\mathrm{Ca}^{2+}$ signal, but not the initial burst $\mathrm{Ca}^{2+}$ rise, was blocked by pre-treatment with an antagonistic cADPR, 8-Br-cADPR (Figure 3C). On the basis of these results that stimulation of CaSR activates ADPR-cyclase in MMC, we evaluated DHAB as a possible candidate inhibitor of ADPRcyclase. This compound was able to inhibit $\left[\mathrm{Ca}^{2+}\right]_{0}-$ mediated later sustained elevation of $\left[\mathrm{Ca}^{2+}\right]_{i}$ but not the initial rise of $\left[\mathrm{Ca}^{2+}\right]_{\mathrm{i}}$ in a dose-dependent manner (Figure 4A-G). Further, $\left[\mathrm{Ca}^{2+}\right]_{0}$-induced production of CADPR was also blocked by pre-treatment of DHAB in a concentration-dependent manner (Figure $4 \mathrm{H}$ ). $\mathrm{IC}_{50}$ was approximately $2.5 \mathrm{nM}$. In addition, since it has been reported that CaSR-mediated $\mathrm{Ca}^{2+}$ signal is involved in MMC proliferation (Kwak et al., 2005), we examined whether DHAB inhibits the $\left[\mathrm{Ca}^{2+}\right]_{0^{-}}$ induced $M M C$ proliferation. As presented in Figure $4 \mathrm{I}$, the $\left[\mathrm{Ca}^{2+}\right]_{0}$-induced increment of proliferation was also inhibited by DHAB in a similar range of concentrations observed in the inhibition of the sustained $\mathrm{Ca}^{2+}$ signal, suggesting that cADPR-induced sustained $6 \mathrm{Ca}^{2+}$ signal regulates MMC proliferation.

An efficacy of DHAB for inhibition of kidney ADPR-cyclase was further evaluated utilizing DAHB 
A

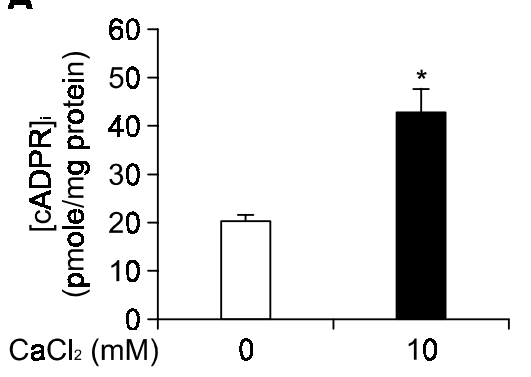

B

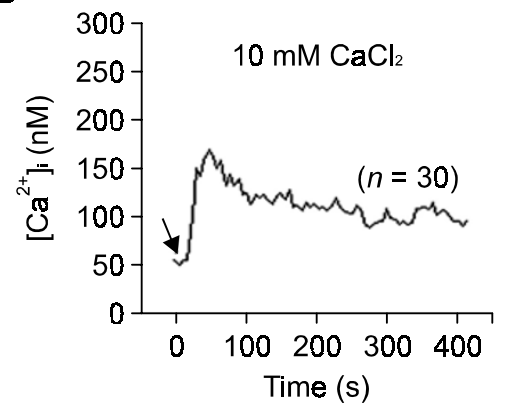

C

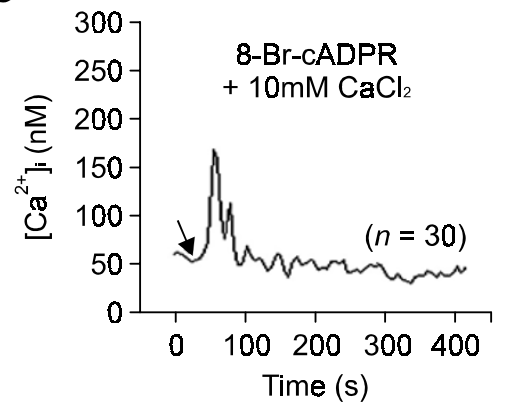

Figure 3. Stimulation of $\mathrm{CaSR}$ with $\left[\mathrm{Ca}^{2+}\right]_{0}$ resulted in a significant increase of $[\mathrm{CADPR}]_{i}$ and a long-lasting $\left[\mathrm{Ca}^{2+}\right]_{\text {. }}$ (A) $[\mathrm{CADPR}] \mathrm{i}$ is increased in response to $10 \mathrm{mM} \mathrm{CaCl}$ treatment. $\mathrm{MMC}$ was incubated with $10 \mathrm{mM} \mathrm{CaCl}{ }_{2}$ at $37^{\circ} \mathrm{C}$ for 2 min. Formation of CADPR was determined as described under Experimental Procedures. The mean \pm SEM of three independent experiments is shown. ${ }^{*}$ Control versus $10 \mathrm{mM} \mathrm{CaCl}_{2}, P<0.001$. (B) Treatment of MMC with $10 \mathrm{mM} \mathrm{CaCl}_{2}$ generates a long-lasting intracellular $\mathrm{Ca}^{2+}$ signal. (C) Pre-treatment of $\mathrm{MMC}$ with 8-Br-cADPR (100 $\left.\mu \mathrm{M}\right)$ for 30 min abolishes $\left[\mathrm{Ca}^{2+}\right]_{0}$-induced sustained $\mathrm{Ca}^{2+}$ increase, whereas the initial $\mathrm{Ca}^{2+}$ increase remains. $n$ indicates the cell numbers.

A

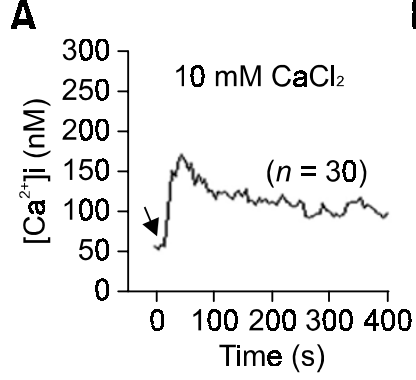

B

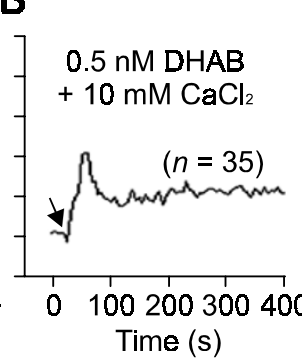

C

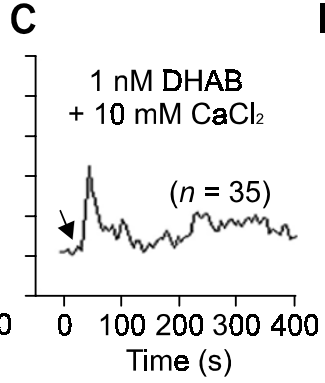

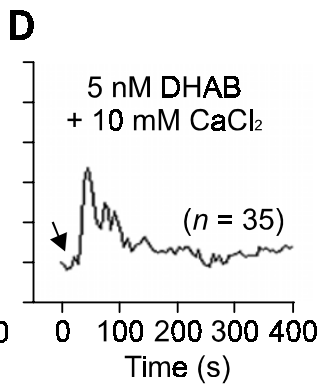

E

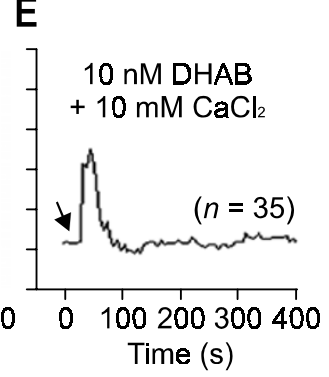

$\mathbf{F}$

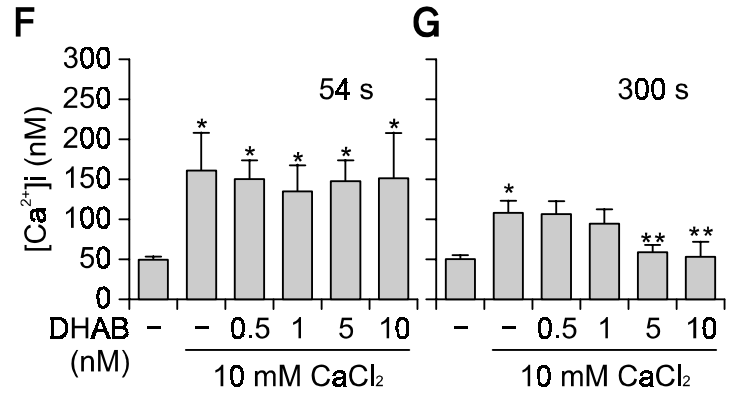

$\mathrm{H}$

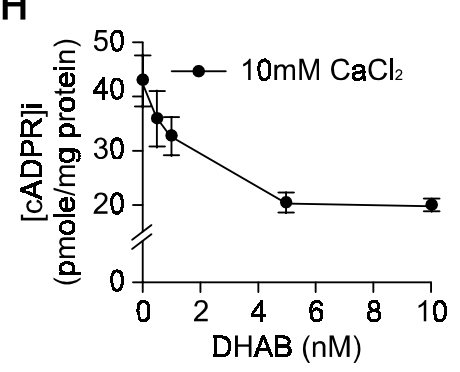

I

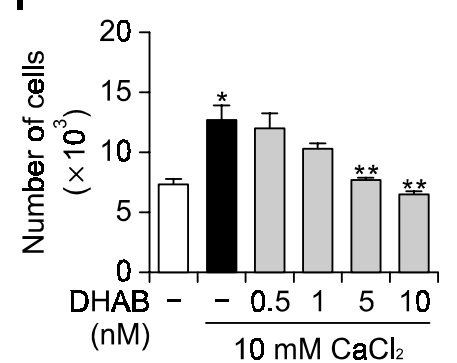

Figure 4. DAHB inhibits $\left[\mathrm{Ca}^{2+}\right]_{0}$-induced $\mathrm{Ca}^{2+}$ signal in $\mathrm{MMC}$ in a concentration-dependent manner. (A) Treatment of $\mathrm{MMC}$ with $10 \mathrm{mM} \mathrm{CaCl} 2$ generates a long-lasting intracellular $\mathrm{Ca}^{2+}$ signal. (B-E) $\left[\mathrm{Ca}^{2+}\right]_{0}$-induced sustained $\mathrm{Ca}^{2+}$ signal in $\mathrm{MMC}$ is inhibited by pre-treatment of various concentrations of $\operatorname{DHAB}(0.5,1,5$, and $10 \mathrm{nM})$ for $1 \mathrm{~h}$. (F) Effects of various concentrations of $\mathrm{DHAB}$ on $\left[\mathrm{Ca}^{2+}\right]_{0}$-induced initial $\mathrm{Ca}^{2+}$ increase in $\mathrm{MMC}^{2}$ at 54 sec. ${ }^{*}$ Control versus $10 \mathrm{mM} \mathrm{CaCl} 2$ or $10 \mathrm{mM} \mathrm{CaCl}_{2}$ versus DHAB, $P<0.001$. (G) Effects of various concentrations of DHAB on [C $\left.{ }^{2+}\right]_{0}$-induced $\mathrm{Ca}^{2+}$ increase in $\mathrm{MMC}$ at $300 \mathrm{~s}$. ${ }^{*}$ Control versus $10 \mathrm{mM} \mathrm{CaCl}, P<0.001$; ${ }^{* *} 10 \mathrm{mM} \mathrm{CaCl} 2$ versus $10 \mathrm{mM} \mathrm{CaCl}$ plus DHAB, $P<0.001$. (H) $\left[\mathrm{Ca}{ }^{2+}\right]_{0}$-induced production of CADPR was blocked by pre-treatment of DHAB in a concentration-dependent manner. (I) DHAB inhibits [C $\left.{ }^{2+}\right]_{0}$-induced increment of proliferation of MMC in a dose-dependent manner. The mean \pm SEM of three independent experiments is shown. ${ }^{*}$ Control versus $10 \mathrm{mM}$ $\mathrm{CaCl}_{2}, P<0.001 ;{ }^{* *} 10 \mathrm{mM} \mathrm{CaCl}_{2}$ versus $10 \mathrm{mM} \mathrm{CaCl}_{2}$ plus DHAB, $P<0.001$.

analogs, 2,2'-dihydroxybenzene and azobenzene, and structurally similar compounds, resveratrol and piceatannol that are known to activate SIRT1 activity, which uses NAD as a cofactor (Howitz et al., 2003). Production of CADPR and the later sustained $\mathrm{Ca}^{2+}$ signal in response to $\left[\mathrm{Ca}^{2+}\right]_{0}$ were inhibited with different efficacy by these small molecules (Table 1). As expected, among these small molecules, DAHB showed the strongest inhibitory potency. The order of $\mathrm{IC}_{50}$ was DAHB > resveratrol > azobenzene $=$ piceatannol $>2,2^{\prime}$-dihydroxy azobenzene. These observations suggest that the biphenyl moiety but 
Table 1. Inhibitory potency of DAHB, DAHB analogs, and structurally similar compounds on $\mathrm{Ca}^{2+}$ signal and cADPR production in response to extracellular calcium.

\begin{tabular}{|c|c|c|c|}
\hline Structure & Compound & $\begin{array}{c}\mathrm{IC}_{50}\left(\left[\mathrm{Ca}^{2+}\right] \mathrm{i}, \mu \mathrm{M}\right) \\
(\text { mean } \pm \mathrm{SEM})\end{array}$ & $\begin{array}{l}\mathrm{IC}_{50}([\mathrm{CADPR}] \mathrm{i}, \mu \mathrm{M}) \\
(\text { mean } \pm \mathrm{SEM})\end{array}$ \\
\hline & 4,4'-Dihydroxy-azobenzene & $0.0025 \pm 0.0002$ & $0.0025 \pm 0.0003$ \\
\hline & 2,2'-Dihydroxy-azobenzene & $15 \pm 1.5$ & $16.5 \pm 2.5$ \\
\hline & Azobenzene & $10 \pm 1.1$ & $13 \pm 2.1$ \\
\hline & $\begin{array}{l}\text { Resveratrol } \\
\text { (3,5,4'-trihydroxy-trans-stillbene) }\end{array}$ & $5 \pm 0.8$ & $5.5 \pm 0.5$ \\
\hline & $\begin{array}{l}\text { Piceatannol } \\
\left(3,5,3^{\prime}, 4^{\prime} \text {-tetrahydroxy-trans-stilbene }\right)\end{array}$ & $10 \pm 1.7$ & $8.9 \pm 1.5$ \\
\hline $\mathrm{OH}$ & & & \\
\hline
\end{tabular}

$\mathrm{IC}_{50}$ of the compounds for cADPR production and the later sustained $\mathrm{Ca}^{2+}$ signal induced by $10 \mathrm{mM} \mathrm{CaCl}_{2}$ was determined after incubation for $90 \mathrm{~s}$ $([\mathrm{CADPR}])$ and $300 \mathrm{~s}\left(\left[\mathrm{Ca}^{2+}\right]\right.$ ) as described in the legend of Figure 4.

not the azo bond and position of hydroxyl group affect the binding of the inhibitor to the enzyme.

Taken together, these data show that DHAB inhibits CADPR production stimulated by CaSR in $\mathrm{MMC}$ at $\leq 5 \mathrm{nM}$ and is far more potent in cell-based system than in vitro. Although the reasons for the different efficacy of the DHAB are not clearly understood, it might be due to the environment of the enzyme location such as membranes versus detergent or due to nonspecific hindrance of other proteins in the enzyme preparation. It is also possible that the kidney enzyme is a transmembrane protein as CD38 is, so that accessibility of $\mathrm{DAHB}$ to the enzyme in the cell system is far greater than that in detergent. A prototype of ADPRcyclases, CD38 is a type II transmembrane protein in which the active site is located at the extracellular domain (Han et al., 2000; An et al., 2001). In fact, the kidney enzyme was found in plasma membrane rich fraction but not cytosol (data not sown).

\section{Specificity of DHAB}

Above results obtained from in vitro study indicated that DHAB is specific for the kidney ADPR-cyclase. To evaluate this finding further, we utilized a human $\mathrm{T}$ cell-derived cell line, Jurkat $\mathrm{T}$ cell. Jurkat $\mathrm{T}$ cells express exclusively CD38 that is regulated by CD3/TCR (Zubiaur et al., 1997). Treatment of Jurkat $T$ cells with OKT3, which is a ligand for CD3/TCR, showed a typical biphasic increase of $\left[\mathrm{Ca}^{2+}\right]_{\mathrm{i}}$, an initial peak rise followed by a sustained rise (Figure $5 A$ ). Pre-treatment with $8-B r-c A D P R$ inhibited only the sustained $\mathrm{Ca}^{2+}$ rise (Figure $5 \mathrm{~B}$ ). In contrast, DHAB did not show any effects on OKT3-mediated $\mathrm{Ca}^{2+}$ rise even at $10 \mu \mathrm{M}$ (Figure $5 \mathrm{C}$ ). Effects of these agents on OKT3-induced $\mathrm{Ca}^{2+}$ signal was summarized in Figure $5 \mathrm{D}$ and $5 \mathrm{E}$. Supporting the 
A

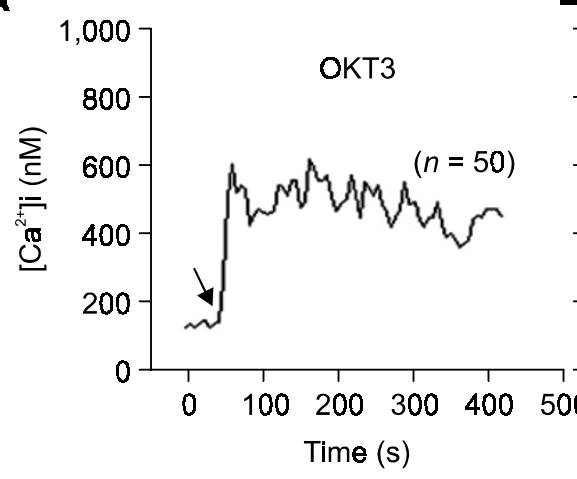

B

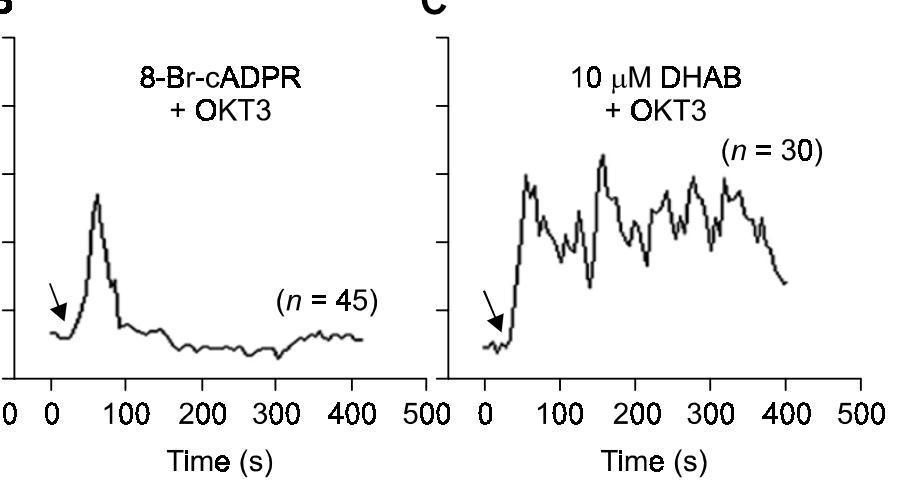

D

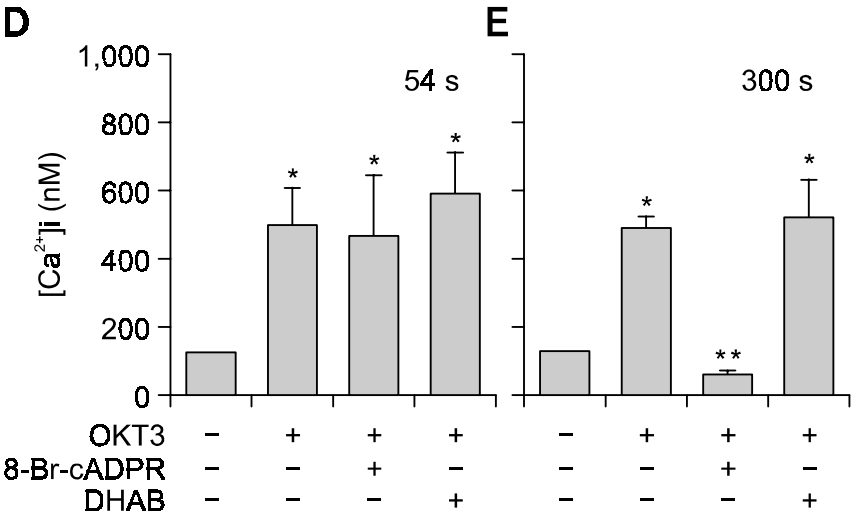

$\mathbf{F}$

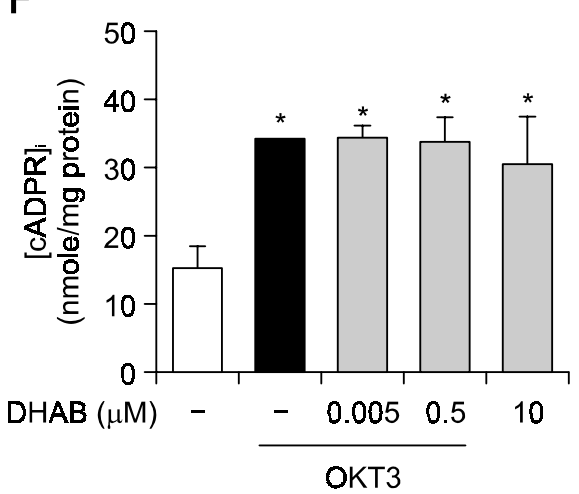

Figure 5. DAHB does not inhibit CD38-involved cADPR production and $\mathrm{Ca}^{2+}$ signal in Jurkat $\mathrm{T}$ cells. (A) Treatment of Jurkat $\mathrm{T}$ cells with $10 \mu \mathrm{g} / \mathrm{ml}$ OKT3 generates a long-lasting intracellular $\mathrm{Ca}^{2+}$ signal. (B) Pre-treatment of Jurkat T cells with 8-Br-cADPR (100 $\left.\mu \mathrm{M}\right)$ for 30 min abolishes OKT3-induced sustained $\mathrm{Ca}^{2+}$ increase, whereas the initial $\mathrm{Ca}^{2+}$ increase remains. (C) Pre-treatment of Jurkat $\mathrm{T}$ cells with DHAB $(10 \mu \mathrm{M})$ for $1 \mathrm{~h}$ has no effect on the long-lasting intracellular $\mathrm{Ca}^{2+}$ signal induced by OKT3. (D) Effects of various agents on OKT3-induced initial $\mathrm{Ca}^{2+}$ increase at $54 \mathrm{~s}$. ${ }^{*}$ Control versus OKT3 or OKT3 plus 8-Br-CADPR or OKT3 plus DHAB, $P<0.001$. (E) Effects of various agents on OKT3-induced $\mathrm{Ca}^{2+}$ increase at $300 \mathrm{~s}$. ${ }^{*}$ Control versus OKT3 or OKT3 plus DHAB, $P<0.001 ;{ }^{* *}$ OKT3 versus OKT3 plus 8-Br-CADPR, $P<0.001$. (F) Effect of various concentrations of DHAB on OKT3-mediated increase of [CADPR]i. Jurkat T cells were incubated with $10 \mu \mathrm{g} / \mathrm{ml}$ OKT3 for $2 \mathrm{~min}$. Formation of CADPR was determined as described under Experimental Procedures. ${ }^{*}$ Control versus OKT3 or OKT3 plus DHAB, $P<0.001$.

observations, OKT3-induced CADPR production was not blocked by pre-treatment with DHAB (Figure 5F).

In the present study, we have discovered a small and potent molecule, DHAB, that inhibits specifically the kidney ADPR-cyclase at $\leq 5 \mathrm{nM}$. The discovery of the specific inhibitor for the enzyme enables us to provide further evidence that there are ADPRcyclases different from CD38. More importantly, our data provide the basis for the discovery of bioactive small-molecule ADPR-cyclase inhibitors, utilizing partially purified enzyme and cell-based system. Benefits of the kidney ADPR-cyclase specific inhibitor are several folds: use of DHAB may facilitate understanding of kidney functions involving regulation of $\mathrm{Ca}^{2+}$ homeostasis; the inhibitor may help to understand pathogenesis of the kidney; this compound can be the basis for development of tissue specific inhibitors of ADPR-cyclases; finally, the compound may be applied to therapeutic purposes for prevention and management of human kidney diseases.

\section{Acknowledgment}

We are grateful to professor S. H. Cha for providing mouse mesangial cells. S.-Y.R. and S.-Y.K. are BK21 recipients. This work was supported by the Korea Science and Engineering Foundation grant R01-2005-000-10933-0 (U.-H.K. and H.J.K).

\section{References}

An NH, Han, MK, Um C, Park BH, Park BJ, Kim HK, Kim UH. 
Significance of ecto-cyclase activity of CD38 in insulin secretion from mouse pancreatic islet cells. Biochem Biophys Res Commun 2001;282:781-6

Boittin FX, Dipp M, Kinnear NP, Galione A, Evans AM. Vasodilation by the calcium-mobilizing messenger cyclic ADP-ribose. J Biol Chem 2003;278:9602-8

Ceni C, Muller-Steffner H, Lund F, Pochon N, Schweitzer A, De Waard M, Schuber F, Villaz M, Moutin MJ. Evidence for an intracellular ADP-ribosyl cyclase/NAD ${ }^{+}$-glycohydrolase in brain from CD38-deficient mice. J Biol Chem 2003;278: 40670-8

de Toledo FG, Cheng J, Liang M, Chini EN, Dousa TP. ADP-ribosyl cyclase in rat vascular smooth muscle cells: properties and regulation. Circ Res 2000;86:1153-9

Fellner SK, Arendshorst WJ. Angiotensin $\mathrm{II} \mathrm{Ca}^{2+}$ signaling in rat afferent arterioles: stimulation of cyclic ADP ribose and $\mathrm{IP}_{3}$ pathways. Am J Physiol Renal Physiol 2005;288:F785-91

Galione A, Churchill GC. Cyclic ADP ribose as a calciummobilizing messenger. Sci STKE 2000;41:PE1

Ge ZD, Zang DX, Chen YF, Yi FX, Zou AP, Campbell WB, Li $\mathrm{PL}$. Cyclic ADP-ribose contributes to contraction and $\mathrm{Ca}^{2+}$ release by $M_{1}$ muscarinic receptor activation in coronary arterial smooth muscle. J Vasc Res 2003;40:28-36

Graeff RM, Walseth TF, Fryxell K, Branton WD, Lee HC. Enzymatic synthesis and characterizations of cyclic GDPribose. A procedure for distinguishing enzymes with ADPribosyl cyclase activity. J Biol Chem 1994;269:30260-7

Graeff R, Lee HC. A novel cycling assay for cellular cADPribose with nanomolar sensitivity. Biochem J 2002;361:37984

Guse AH, da Silva CP, Berg I, Skapenko AL, Weber K, Heyer $\mathrm{P}$, Hohenegger M, Ashamu GA, Schulze-Koops H, Potter BV, Mayr GW. Regulation of calcium signalling in T lymphocytes by the second messenger cyclic ADP-ribose. Nature 1999; 398:70-3

Han MK, Cho YS, Kim YS, Yim CY, Kim UH. Interaction of two classes of ADP-ribose transfer reactions in immune signaling. J Biol Chem 2000;275:20799-805

Higashida H, Egorova A, Higashida C, Zhong ZG, Yokoyama $S$, Noda M, Zhang JS. Sympathetic potentiation of cyclic ADP-ribose formation in rat cardiac myocytes. J Biol Chem 1999;274:33348-54

Higashida H, Zhang J, Hashii M, Shintaku M, Higashida C, Takeda Y. Angiotensin II stimulates cyclic ADP-ribose formation in neonatal rat cardiac myocytes. Biochem J 2000; 352:197-202

Hirata Y, Kimura N, Sato K, Ohsugi Y, Takasawa S, Okamoto $\mathrm{H}$, Ishikawa J, Kaisho $\mathrm{T}$, Ishihara $\mathrm{K}$, Hirano T. ADP ribosyl cyclase activity of a novel bone marrow stromal cell surface molecule, BST-1. FEBS Lett 1994;356:244-8

Howitz KT, Bitterman KJ, Cohen HY, Lamming DW, Lavu S, Wood JG, Zipkin RE, Chung P, Kisielewski A, Zhang LL, Scherer B, Sinclair DA. Small molecule activators of sirtuins extend Saccharomyces cerevisiae lifespan. Nature 2003;425: 191-6
Kim SY, Kim SJ, Kim BJ, Rah SY, Chung SM, Im MJ, Kim UH. Doxorubicin-induced reactive oxygen species generation and intracellular $\mathrm{Ca}^{2+}$ increase are reciprocally modulated in rat cardiomycytes. Exp Mol Med 2006;38:535-45

Kukimoto I, Hoshino S, Kontani K, Inageda K, Nishina H, Takahashi K, Katada T. Stimulation of ADP-ribosyl cyclase activity of the cell surface antigen CD38 by zinc ions resulting from inhibition of its $\mathrm{NAD}^{+}$glycohydrolase activity. Eur $\mathrm{J}$ Biochem 1996;239:177-82

Kwak JO, Kwak J, Kim HW, Oh KJ, Kim YT, Jung SM, Cha SH. The extracellular calcium sensing receptor is expressed in mouse mesangial cells and modulates cell proliferation. Exp Mol Med 2005;37:457-65

Kwon HJ. Chemical genomics-based target identification and validation of anti-angiogenic agents. Curr Med Chem 2003; 10:717-36

Lee HC, Aarhus R. ADP-ribosyl cyclase: an enzyme that cyclizes $\mathrm{NAD}^{+}$into a calcium-mobilizing metabolite. Cell Regul $1991 ; 2: 203-9$

Lee HC. Physiological functions of cyclic ADP-ribose and NAADP as calcium messengers. Annu Rev Pharmacol Toxicol 2001:41:317-45

Lee HC. Multiplicity of $\mathrm{Ca}^{2+}$ messengers and $\mathrm{Ca}^{2+}$ stores: a perspective from cyclic ADP-ribose and NAADP. Curr Mol Med 2004; 4:227-37

Partida-Sanchez S, Cockayne DA, Monard S, Jacobson EL, Oppenheimer N, Garvy B, Kusser K, Goodrich S, Howard M, Harmsen A, Randall TD, Lund FE. Cyclic ADP-ribose production by CD38 regulates intracellular calcium release, extracellular calcium influx and chemotaxis in neutrophils and is required for bacterial clearance in vivo. Nat Med 2001; 7:1209-16

Schreiber SL. Chemical genetics resulting from a passion for synthetic organic chemistry. Bioorg Med Chem 1998;6:112752

Sternfeld L, Krause E, Guse AH, Schulz I. Hormonal control of ADP-ribosyl cyclase activity in pancreatic acinar cells from rats. J Biol Chem 2003;278:33629-36

Tsien RY, Pozzan T, Rink, TJ. T-cell mitogens cause early changes in cytoplasmic free $\mathrm{Ca}^{2+}$ and membrane potential in lymphocytes. Nature 1982;295:68-71

Walseth TF, Lee HC. Synthesis and characterization of antagonists of cyclic-ADP-ribose-induced $\mathrm{Ca}^{2+}$ release. Biochim Biophys Acta 1993;1178:235-42

White TA, Johnson S, Walseth TF, Lee HC, Graeff RM, Munshi CB, Prakash YS, Sieck GC, Kannan MS. Subellular localization of cyclic ADP-ribosyl cyclase and cyclic ADPribose hydrolase activities in porcine airway smooth muscle. Biochim Biophys Acta 2000;1498:64-71

Xie GH, Rah SY, Kim SJ, Nam TS, Ha KC, Chae SW, Im MJ and Kim UH. ADP-ribosyl cyclase couples to cAMP signaling in the cardiomyocytes. Biochem Biophys Res Commun 2005;330:1290-8

Zielinska W, Barata $H$, Chini EN. Metabolism of cyclic ADP-ribose: Zinc is an endogenous modulator of the 
cyclase/NAD glycohydrolase ratio of a CD38-like enzyme from human seminal fluid. Life Sci 2004;74:1781-90

Zubiaur M, Izquierdo M, Terhorst C, Malavasi F, Sancho J.
CD38 ligation results in activation of the Raf-1/mitogenactivated protein kinase and the CD3-zeta/zeta-associated protein-70 signaling pathways in Jurkat $\mathrm{T}$ lymphocytes. J Immunol 1997;159:193-205 